\title{
Article \\ Mechanical and Thermal Properties of Insulating Sustainable Mortars with Ampelodesmos mauritanicus and Pennisetum setaceum Plants as Aggregates
}

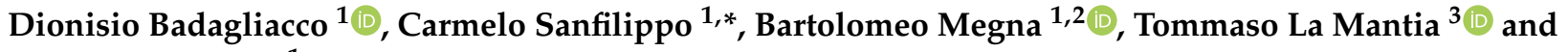 \\ Antonino Valenza ${ }^{1}$ \\ 1 Department of Engineering, University of Palermo, 90128 Palermo, Italy; \\ dionisio.badagliacco@unipa.it (D.B.); bartolomeo.megna@unipa.it (B.M.); antonino.valenza@unipa.it (A.V.) \\ 2 INSTM Research Unity of Palermo, 90128 Palermo, Italy \\ 3 Department of Agricultural, Food and Forest Sciences, University of Palermo, 90128 Palermo, Italy; \\ tommaso.lamantia@unipa.it \\ * Correspondence: carmelo.sanfilippo01@unipa.it
}

check for updates

Citation: Badagliacco, D.; Sanfilippo, C.; Megna, B.; La Mantia, T.; Valenza, A. Mechanical and Thermal

Properties of Insulating Sustainable Mortars with Ampelodesmos mauritanicus and Pennisetum setaceum Plants as Aggregates. Appl. Sci. 2021, 11, 5910. https://doi.org/10.3390/ app11135910

Academic Editor: Doo-Yeol Yoo

Received: 14 May 2021

Accepted: 22 June 2021

Published: 25 June 2021

Publisher's Note: MDPI stays neutral with regard to jurisdictional claims in published maps and institutional affiliations.

Copyright: (c) 2021 by the authors. Licensee MDPI, Basel, Switzerland. This article is an open access article distributed under the terms and conditions of the Creative Commons Attribution (CC BY) license (https:// creativecommons.org/licenses/by/ $4.0 /)$.

\begin{abstract}
The use of natural fibers in cement composites is a widening research field as their application can enhance the mechanical and thermal behavior of cement mortars and limit their carbon footprint. In this paper, two different wild grasses, i.e., Ampelodesmos mauritanicus, also called diss, and Pennisetum setaceum, also known as crimson fountaingrass, are used as a source of natural aggregates for cement mortars. The main purpose is to assess the possibility of using the more invasive crimson fountaingrass in place of diss in cement-based vegetable concrete. The two plant fibers have been characterized by means of scanning electron microscopy (SEM), helium picnometry and thermogravimetric analysis. Moreover, the thermal conductivity of fiber panels has been measured. Mortars samples have been prepared using untreated, boiled and Polyethylene glycol 4000 (PEG) treated fibers. The mechanical characterization has been performed by means of three point bending and compression tests. Thermal conductivity and porosity have been measured to characterize physical modification induced by fibers' treatments. The results showed better thermal and mechanical properties of diss fiber composites than fountaingrass one and that fiber treatments lead to a reduction of the thermal insulation properties.
\end{abstract}

Keywords: natural fibers; reinforced mortar; thermal conductivity; sustainable mortar; mechanical characterization; surface treatments; diss; crimson fountaingrass

\section{Introduction}

In the last decades, a significant amount of relevant research has been carried out concerning the use of lignocellulosic materials in cementititous matrices for building applications. For their high sustainability and good physical and mechanical properties, natural fibers find practical applications in composite materials for automotive parts and building construction panels and furniture [1,2]. Residues of sisal, banana tree, common reed and eucalyptus have been used as reinforcement of cement leading to good mechanical performance of the composites [3-7]. The terms Agro-concrete or green concrete are defined as a mix between granulates from lignocellulosic plant (directly or indirectly from agriculture or forestry origin), which represent the bulk of the volume, and a mineral binder [8].

In this study, the characterization of eco-sustainable composite materials in the field of green building, for application as insulating plasters has been performed. Diss (Ampelodesmos mauritanicus) and Crimson Fountaingrass (Pennisetum setaceum), have been used as aggregates for cement mortars. Pennisetum setaceum is an invasive plant that is gradually replacing the Ampelodesmos mauritanicus in Italy [9]. Alien invasive plants represent one of the main threats to biological diversity on a world-wide scale, and 
hard effort is required every year to ward off, control and eradicate them [10]. In Sicily, Pennisetum setaceum is one of the most aggressive and quick invaders of coastal and hilly areas. During the 70 years following its first introduction, it has established and spread over many coastal areas up to 600 m.a.s.l. and especially on south-facing slopes within the thermo-Mediterranean belt [11]. It has also invaded $H$. hirta thermo-xeric grasslands and even the more mesophilous Ampelodesmos mauritanicus grasslands. It is likely to continue to spread into many other favorable localities, with significant and long-lasting environmental consequences [12]. On the basis of these considerations, this research was aimed to assess the possibility of using crimson fountaingrass in place of diss, which in previous works has already been used as an aggregate for green concrete $[8,13]$, in order to promote the eradication of this invasive plant with fundamental benefits for the biodiversity of the territory.

\section{Materials and Methods}

\subsection{Raw Materials}

\subsubsection{Diss (Ampelodesmos mauritanicus)}

Diss (Figure 1) is a large grass widespread growing in the Mediterranean North Africa and in the dry regions of Greece to Spain, Balkans, Turkey and Asia Minoris. In France, it is established in the departments of Var, Southern Corsica, and Herault. It is a perpetual plant of the Poaceae family, which lives in arid and sandy soils, often in neat associations, typical of the Mediterranean grasslands. In Sicily, Ampelodesmos grasslands are commonly found from 0 to $1200 \mathrm{~m}$ a.s.l., chiefly within the meso Mediterranean and thermo-mediterranean bioclimatic belts [11]. It is composed of strong leaves, up to $1 \mathrm{~m}$ long and about $7 \mathrm{~mm}$ wide, very rough, with tortuous edges. The long and tough leaves can be sharp for the skin if scrubbed between fingers. This plant was previously used in the construction of old dwellings because of its mechanical and physical properties [14]. Its fibrous feature, with a thorny surface may confer high adhesion to the cement paste and hence promising properties to green concrete [15]. In the literature, it is reported a Tensile Strength of $100 \mathrm{MPa}$, Density of $850 \mathrm{~g} / \mathrm{cm}^{3}$, Modulus of Elasticity $2.17 \mathrm{GPa}$ and a Water Absorption Coefficient at saturation of $112 \%[16,17]$.

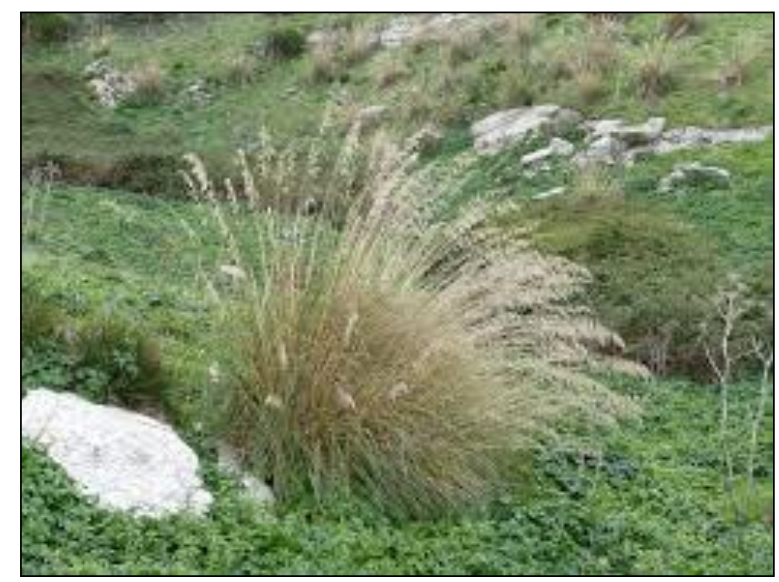

Figure 1. Diss (Ampelodesmos mauritanicus) plant.

\subsubsection{Crimson Fountaingrass (Pennisetum setaceum)}

Pennisetum setaceum (Figure 2) is a plant of the Poaceae family. The species is native to North Africa, the Middle East and the Arabian peninsula. Introduced by humans in many other geographic areas as a decorative plant, it has demonstrated to be a highly invasive species. It is a permanent herbaceous plant, with a bushy growth, up to $1.20 \mathrm{~m}$ high. The ears are dark pink and progressively lighten with maturation, thus creating a variety of shades of color on the same plant. Pennisetum plant was introduced in Sicily as a decorative plant during the 1940s and just twenty years later it began to regenerate 
naturally, spreading into surrounding areas [18]. Currently, it has successfully invaded many coastal and hilly areas up to $500 \mathrm{~m}$ a.s.l., mainly on south-facing slopes within the thermo-Mediterranean bioclimatic belt [11].

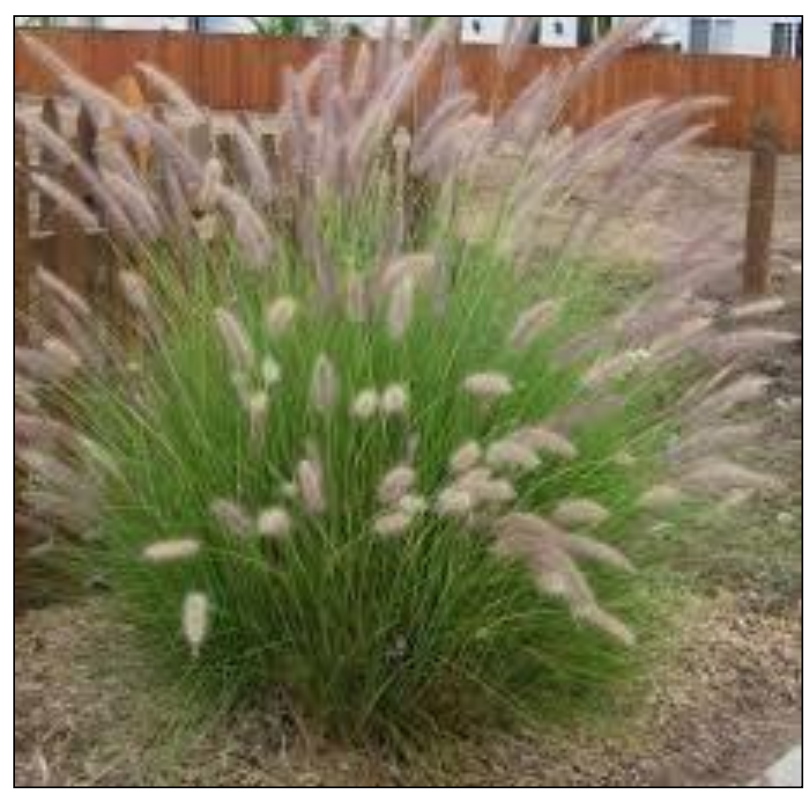

Figure 2. Crimson Funtaingrass (Pennisetum setaceum) plant.

\subsubsection{Binder (i.pro Plastocem)}

The binder used in this study is i.pro Plastocem a Hydraulic Binder according to the UNI 10892-1 standard. The compression strength at 28 days is higher or equal than 3.0 MPa, it belongs to the 3.0 class and is defined as "UNI 10892 LIC" 3.0. It is used for the production of mortars for internal and external plasters. PLASTOCEM is also suitable for the construction of mortars for masonry and substrates for floors. It is composed of a white cement and a calcareous filler as reported in the literature [19]. The result of the STA (Figure 3) on the binder shows the presence of gypsum and calcium hydroxide, but no exothermic peaks associated with the presence of organic substances are observed. The content of calcium carbonate, linked to the final weight drop (30\%), is around $68 \%$. Therefore, it is possible to state that it is a predominantly cement-based binder.

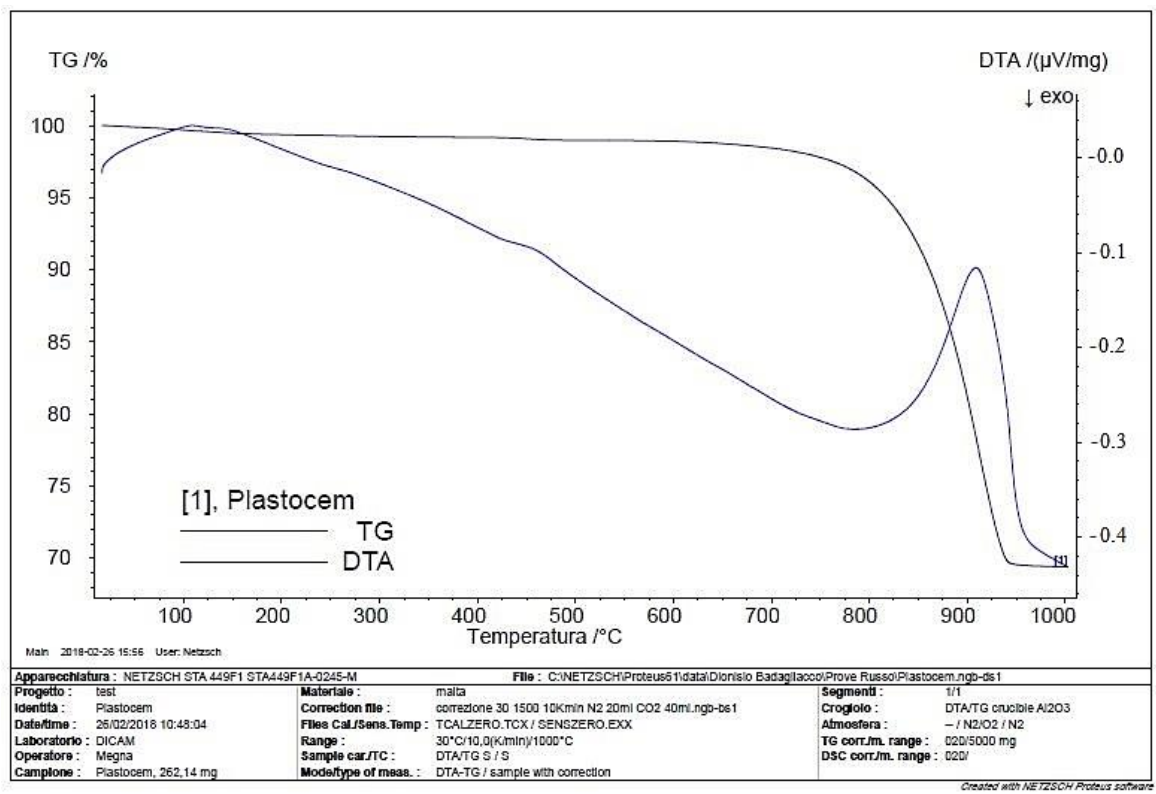

Figure 3. STA result of the Hydraulic Binder (i.pro Plastocem). 


\subsection{Pretreatment of the Aggregates}

The fibers used for their physical and chemical characterization and for the preparation of the mortars were obtained, for both the plants, as follows (Figure 4):

- The stems were obtained from the raw plants and dried in oven at a temperature of $70{ }^{\circ} \mathrm{C}$ for $72 \mathrm{~h}$ until constant mass, in order to minimize the influence of the moisture content and hence to standardize the physical characteristics of the fibers. The drying temperature was set to $70{ }^{\circ} \mathrm{C}$ since it allows a relatively rapid drying of the fibers, which is preferable for the industrial development of the process, without modifying the chemical structure as evidenced by the STA results (Figure 3);

- After the drying process, part of the stems were subjected to a thermal treatment by boiling for $4 \mathrm{~h}$ with distilled water in order to remove the sugars and extractives and then repeatedly washed with distilled water to clean their surface until the water became clean. This treatment was performed because the dissolution of sugars from vegetable fibers during the setting of the cement can act as a retarding agent for the cement paste [13]. The extracts of vegetable matters, in fact, consist mainly of hemicellulose polysaccharides that are supposed to delay the setting of the cement paste $[20,21]$. After that, the treated fibers were dried in oven at a temperature of $70{ }^{\circ} \mathrm{C}$ until constant mass;

- The boiling and drying treatment is followed by a surface treatment. This treatment consists of the immersion in a solution of distilled water and Polyethylene Glycol 4000 (PEG) at $40 \%$ by weight for two hours, followed by $24 \mathrm{~h}$ during which the fibers were left to drip before further drying in the oven until they reached a constant mass;

- Both treated and untreated stems were cut with a knife mill Retsch SM100 (Haan, Germany) operating at $1500 \mathrm{rpm}$ using a mesh of $2 \mathrm{~mm}$;

- After the cutting process, the fibers were water-saturated in a container at $25{ }^{\circ} \mathrm{C}$ and humidity close to $100 \%$ R.H. before using them for the preparation of the mortars. This process makes it possible to obtain a better workability of the mortars without increasing the $\mathrm{w} / \mathrm{b}$ ratio.

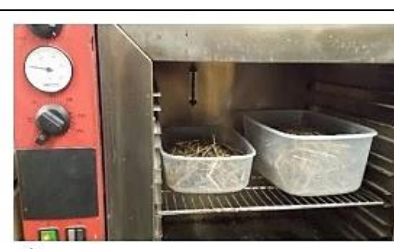

a)

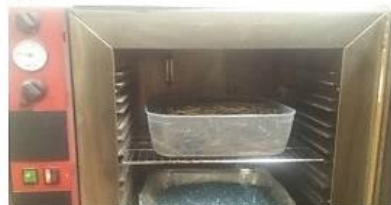

d)

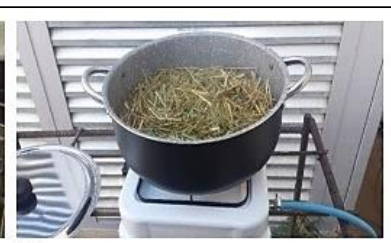

b)

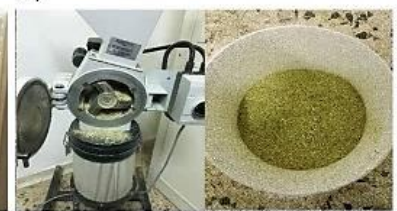

e)

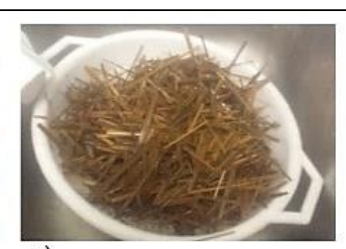

c)

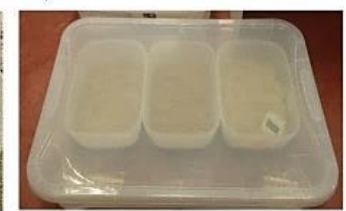

f)

Figure 4. Procedure for the preparation of the fibers (example for boiled Diss fibers): (a) drying; (b) boiling; (c) washing; (d) drying; (e) cutting; (f) water saturation.

\subsection{Characterization of the Fibers}

For both the type of plants, untreated and boiled fibers have been physically and chemically characterized, in order to assess the effect of the thermal treatment on the absolute density (helium picnometer analysis), morphology (SEM) and elemental composition (SEM and STA). Furthermore, heat conductivity (heat flow meter test) of the untreated fibers have been evaluated in order to estimate the insulating properties of both the type of plants. 


\subsubsection{Helium Picnometry}

The real densities of untreated and boiled fibers were evaluated through helium picnometry analysis in a Picnomatic ATC Thermo Fisher Scientific (Bohemia, NY, USA) picnometer. The values were recorded as the average of at least 8 good measures (maximum standard deviation of $0.05 \%$ ) in a maximum of 15 test cycles.

\subsubsection{Scanning Electron Microscopy (SEM)}

Untreated and boiled fibers have been observed in the low vacuum mode in a scanning electron microscope in order to study the morphology of the two species of plants and their modification induced by the thermal treatment. The images have been captured both in SE and BSE mode by setting a high voltage of $30 \mathrm{kV}$ a spot size of $4 \mathrm{~nm}$ and a nominal working distance of $10 \mathrm{~mm}$. Quantitative EDX analysis of the ashes was performed in order to study the elemental composition. In particular, the amount of silicon in the fibers has been evaluated.

\subsubsection{Simultaneous Thermal Analysis (STA)}

Simultaneous thermal analysis was performed using the Netzsch STA 449 Jupiter F1 (Weimar, Germany) instrument. The tests were performed in the $30-1100{ }^{\circ} \mathrm{C}$ range, with $10{ }^{\circ} \mathrm{C} / \mathrm{min}$ heating rate, $20 \mathrm{~mL} / \mathrm{min}$ nitrogen flux and $40 \mathrm{~mL} / \mathrm{min}$ air flux.

\subsubsection{Heat Flow Meter Test}

For the thermal conductivity characterization of the fibers, a LaserComp FOX314 TAinstruments (New Castle, DE, USA) heat flow meter was used according to the standard ASTM C518. From polystyrene panels of size $300 \times 300 \times 40 \mathrm{~mm}$ a square cavity of dimensions $150 \times 150 \times 40 \mathrm{~mm}$ was obtained. It was filled with dried fibers, and the panels were wrapped with paper and weighed in order to evaluate the apparent density of the pile of fibers before performing the thermal test. The values of the heat conductivity of the panels were evaluated once reached the steady state of the thermal flux between the upper and lower plates set to $25^{\circ} \mathrm{C}$ and $5{ }^{\circ} \mathrm{C}$, respectively.

\subsection{Preparation of the Mortars}

Four different types of mortars and the cement paste, used as reference, were prepared. These are defined as follows:

- CEM: Cement paste;

- CEM_30AM: Mortar constituted of binder and 30\% by total volume of diss fibers;

- CEM_30BAM: Mortar constituted of binder and 30\% by total volume of boiled diss fibers;

- CEM_30TAM: Mortar constituted of binder and 30\% by total volume of PEG treated diss fibers;

- CEM_30PS: Mortar constituted of binder and 30\% by total volume of crimson fountaingrass fibers;

- CEM_30BPS: Mortar constituted of binder and 30\% by total volume of boiled crimson fountaingrass fibers;

- CEM_30TPS: Mortar constituted of binder and 30\% by total volume of PEG treated crimson fountaingrass fibers

In order to evaluate the proper amount of water for each mixture, the test for the determination of the consistence of fresh mortar (by flow table) has been carried out on a Controls 63-L0037-E flow table according to the standard UNI EN1015-3. It was thus calculated the water/binder ratio for every type of mortar, which led to the same workability corresponding to flow values of the mixture between 13.5 and $14 \mathrm{~cm}$.

For CEM_30AM, CEM_30BAM and CEM_30TAM mortars, the water/binder ratio used was equal to 0.38 while for those CEM_30PS, CEM_30BPS and CEM_30TPS it was 0.40. For the Cement paste it was 0.28. 
Three samples for each type of mortar have been prepared by using prismatic steel molds of dimensions $40 \times 40 \times 160 \mathrm{~mm}$ according to the EN UNI 1015-11 standard in order to perform the mechanical characterization through the three-point bending and compression tests. Disks of $5 \mathrm{~cm}$ of diameter have been prepared for the thermal characterization, by using cylindrical PVC tubes as molds. The setting and hardening of the mortars occurred for 7 days within the molds and for 21 days after demolding in laboratory conditions at $21^{\circ} \mathrm{C}$ and $60 \%$ of R.H.

\subsection{Characterization of the Mortars}

\subsubsection{Three-Point Bending Test}

At least three specimens of each type of mortar were tested according to the standard EN 1015-11 to evaluate the flexural strength at 28 days. Before performing the tests, the actual dimensions (length, thickness and width) of each sample have been recorded with the aid of a centesimal caliper. The reported measurement was the average of three different measures. Three point bending test has been performed in displacement control mode in a Zwick/Roell Z005 testing machine equipped with a $5 \mathrm{kN}$ capacity load cell. The crosshead speed was $0.5 \mathrm{~mm} / \mathrm{min}$ in order to induce the rupture of the specimens within $1 \div 2 \mathrm{~min}$. The preload was $20 \mathrm{~N}$, while the span length was set to $100 \mathrm{~mm}$. The flexural strength was calculated using the following Equation (1)

$$
\sigma_{b}=\frac{3 P_{\max } L}{2 b h^{2}}
$$

where $P_{\max }$ is the maximum flexural load, $L$ is the span length, $b$ and $h$ are respectively the width and thickness of the specimen.

\subsubsection{Compressive Test}

For each mortar mix, six specimens were tested, and the results reported as average and standard deviation of the maximum compression strength obtained from the valid tests (at least 5 for each type). The tests were carried out in force control on the halves of the samples previously tested in bending, in a Universal Electromechanical Machine MP Strumenti Tools WANCE UTM 502 equipped with a $50 \mathrm{kN}$ capacity load cell. The loading speed was equal to $200 \mathrm{~N} / \mathrm{s}$ for CEM mortars, 100 N/s for CEM_30AM, CEM_30BAM and CEM_30TAM mortars and 50 N/s for CEM_30PS, CEM_30BPS and CEM_30TPS in order to induce the rupture of all the specimens within $30 \mathrm{~s}$ and $90 \mathrm{~s}$ according to the standard EN 1015-11. A compression jig assembly was used in order to compensate the lack of parallelism between the loaded surfaces of the specimen during the compression test. The compression strength values for each sample were obtained by dividing the maximum load by the resistant cross section of the specimen $\left(40 \times 40 \mathrm{~mm}^{2}\right)$.

\subsubsection{Heat Flow Meter Test}

Disks between $2 \mathrm{~cm}$ and $2.5 \mathrm{~cm}$ of thickness were cut from the cylinders after 28 days of hardening by means of an IMER COMBI $250 \mathrm{~V}$ (Poggibonsi, Italy) water-cooled saw. Before the execution of tests, the samples were dried in oven at $60^{\circ} \mathrm{C}$ for $24 \mathrm{~h}$ until constant mass, in order to eliminate the water absorbed by the samples after the cutting process and to prevent any discrepancy of results caused by variable moisture contents. Then the specimens have been polished using a PRESI-Mecapol-2B (Eybens Auvergne, France) polishing machine in order to obtain a uniform thermal flow and low contact thermal resistances. Minimum three samples for each type of mortar were tested in a LaserComp FOX 50 TA-instruments (New Castle, DE, USA) heat flow meter according to ASTM C518 and ISO 8301. The values of thermal conductivity were evaluated through the following Equation (2):

$$
\lambda=\frac{s q}{\Delta T}\left[\frac{W}{m K}\right]
$$


where $s$ is the sample thickness, $q$ is the heat flux at the steady state and $\Delta T$ is the difference between the upper and lower plates temperature respectively set to $25^{\circ} \mathrm{C}$ and $15^{\circ} \mathrm{C}$. The results were reported as average and standard deviations.

\subsubsection{Helium Picnometry}

After performing the mechanical tests, fragments from the crushed samples have been analysed by means of helium picnometry in a Picnomatic ATC Thermo Fisher Scientific (Bohemia, NY, USA) picnometer in order to assess the porosity of the mortars. The values of real density were calculated as the average of at least 8 good measures (maximum standard deviation of $0.05 \%$ ) in a maximum of 15 test cycles. The porosity of the mortars was obtained by using the following Equation (3):

$$
\text { Porosity }[\%]=100\left(1-\frac{\rho_{\text {app }}}{\rho_{\text {real }}}\right)
$$

where: $\rho_{a p p}$ is the apparent density, measured as the mass by volume ratio of the prismatic samples before the flexural test, and $\rho_{\text {real }}$ is the real density.

\section{Results and Discussion}

The results of helium picnometry analysis on untreated and boiled fibers (Figure 5) showed that the thermal treatment is supposed to modify the chemical composition of the diss fibers probably due to the removal of sugar and extractives as also reported by other authors in the literature $[8,13]$.

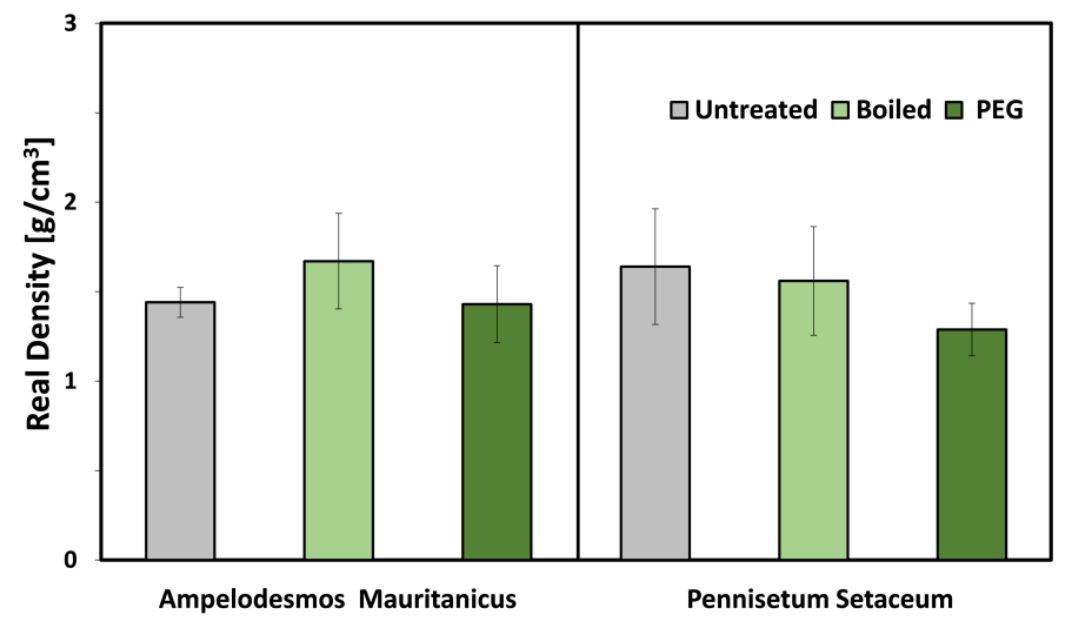

Figure 5. Density results of untreated and treated diss and crimson fountaingrass fibers.

SEM image analysis of the two types of plants (Figure 6) evidenced the different surface morphology between diss and crimson fountaingrass fibers. In fact, the former are characterized by the presence of spines, which may improve the adhesion between fibers and cementitious matrix due to the better mechanical interlocking, while the latter present a smooth surface. It is also important noting that the thermal treatment does not affect the morphology of the fibers as can be demonstrated by observing the Figure 7 that shows the permanence of the spines on the diss fibers' surface after the boiling treatment. Quantitative EDX analysis (Figure 8) on the ashes of untreated diss and crimson fountaingrass evidenced the higher content of silicon in the former (approximately $22 \%$ by weight) compared to the latter (approximately 9\%). This result may indicate that diss fibers are characterized by either better mechanical properties or higher reactivity with the cementitious matrix. The latter can be due to the $\mathrm{SiO}_{2}$ content in the fibers may react with the portlandite present in the matrix to produce further calcium silicate hydrates which are responsible for the mechanical properties of the cement. The STA results confirmed those obtained by 
EDX since the amount of uncombusted was higher for the diss rather than the crimson fountaingrass fibers (Figure 9).

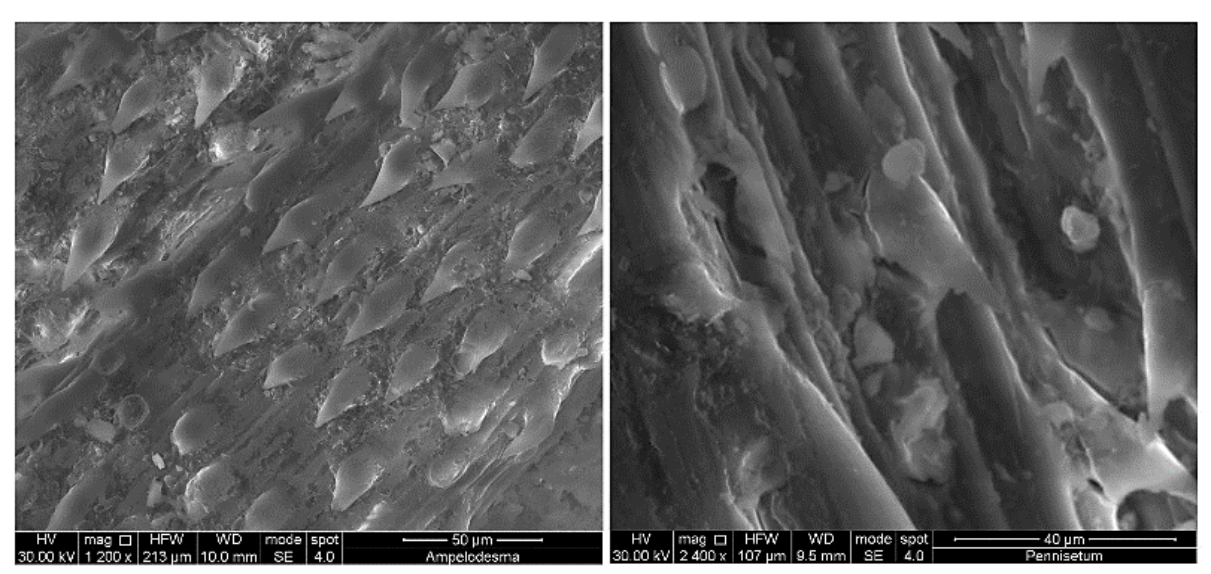

Figure 6. Comparison between untreated diss (left) and crimson fountaingrass fibers (right).
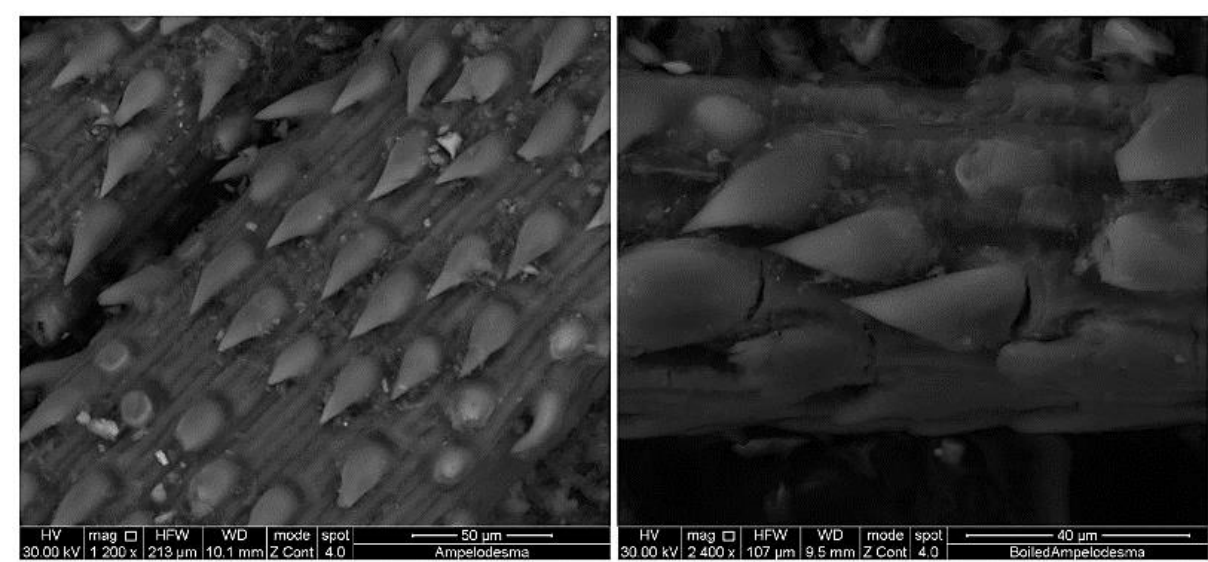

Figure 7. Comparison between untreated (left) and boiled (right) diss fibers.
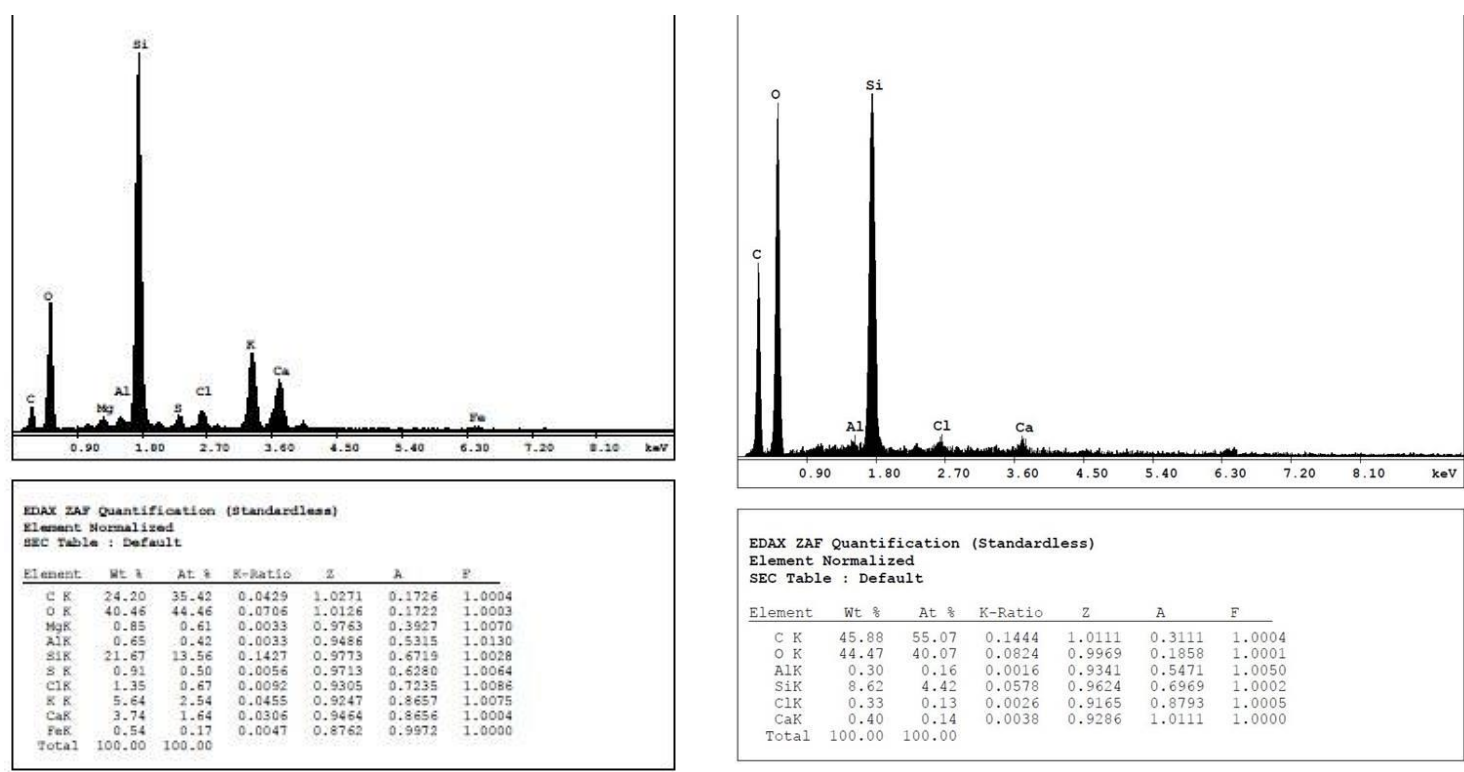

Figure 8. Comparison of quantitative elemental composition between diss (left) and crimson fountaingrass ashes (right). 

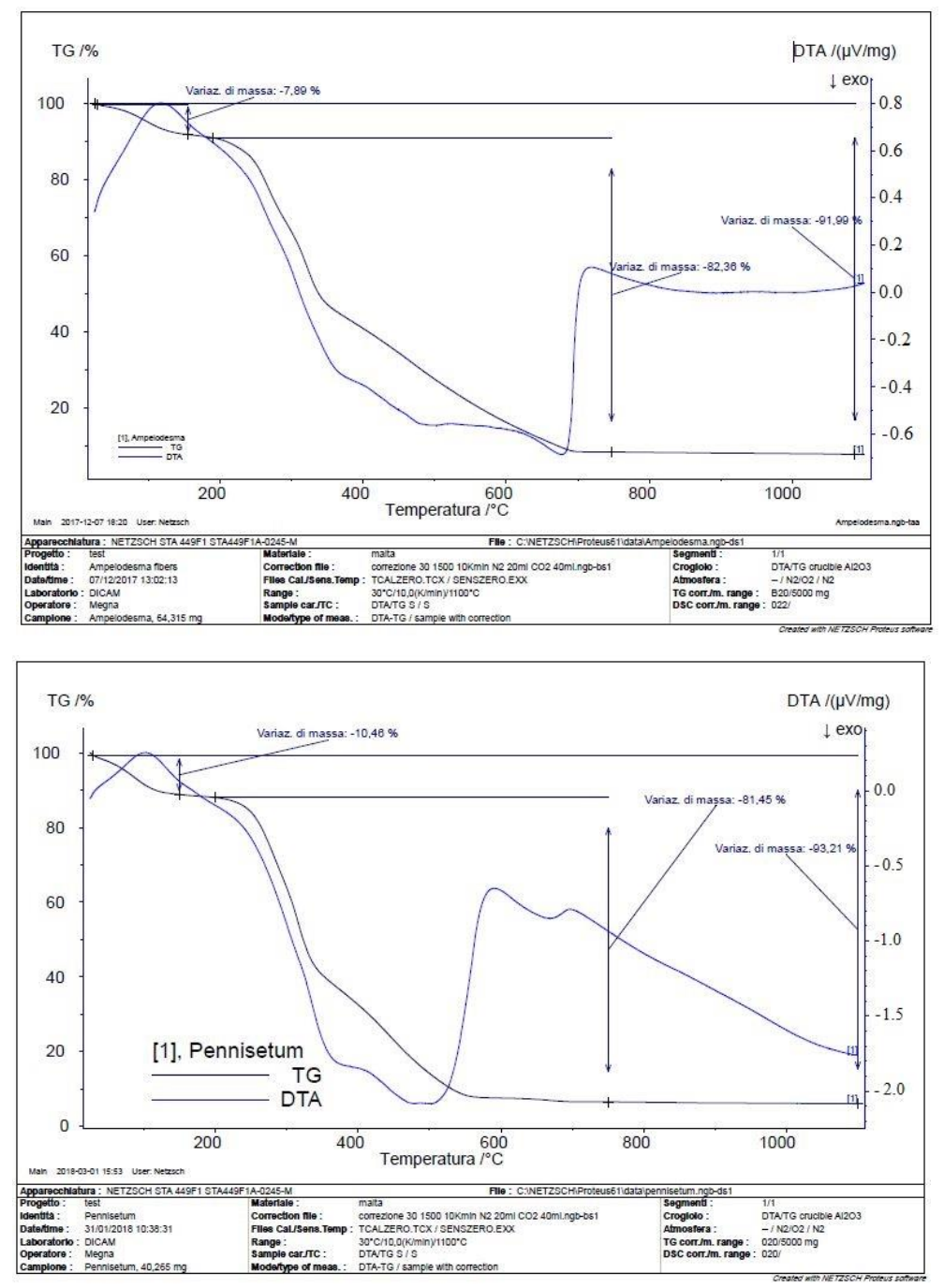

Figure 9. STA of diss (above) and crimson fountaingrass (below) fibers.

The results of the heat flow meter test of the fibers shown in Table 1 evidenced good insulating properties of both the types of plants with values of thermal conductivity equal to $0.059 \mathrm{~W} / \mathrm{mK}$ and $0.054 \mathrm{~W} / \mathrm{mK}$, respectively for diss and crimson fountaingrass aggregates. These results are in accordance to the higher apparent density of the pile of the Ampelodesmos mauritanicus fibers compared to the Pennisetum setaceum ones (Table 1).

Table 1. Thermal conductivity and Apparent density of the aggregates.

\begin{tabular}{|c|c|c|c|c|}
\hline $\begin{array}{c}\text { Type of } \\
\text { Aggregate }\end{array}$ & $\begin{array}{c}\text { Thermal } \\
\text { Conductivity } \lambda \\
(\mathrm{W} / \mathrm{mK})\end{array}$ & $\begin{array}{c}\text { Amount of } \\
\text { Aggregate (g) }\end{array}$ & Volume $\left(\mathrm{cm}^{3}\right)$ & $\begin{array}{c}\text { Apparent } \\
\text { Density of the } \\
\text { Pile }\left(\mathrm{g} / \mathrm{cm}^{3}\right)\end{array}$ \\
\hline $\begin{array}{l}\text { Ampelodesmos } \\
\text { mauritanicus }\end{array}$ & 0.059 & 280.4 & 900 & 0.312 \\
\hline $\begin{array}{l}\text { Pennisetum } \\
\text { setaceum }\end{array}$ & 0.054 & 240.5 & 900 & 0.267 \\
\hline
\end{tabular}

The results of the mechanical tests (Figures 10 and 11) on the mortars showed that diss aggregate leads to better performances both in terms of flexural and compression strength compared to crimson fountaingrass one. This can be due to either the better morphology or the chemical composition of the diss compared to the crimson fountaingrass fibers as verified by the results of the fibers' characterization. The thermal treat- 
ment significantly improves the mechanical properties of the mortars additivated with Ampelodesmos mauritanicus aggregates. This can be probably attributed to the chemical modification of the diss fibers (as confirmed by the increase in the real density) which leads to better compatibility between natural fibers and matrix, allowing the correct setting and hardening of the cement as also evidenced by other works reported in the literature $[8,13]$. The surface treatment of the fibers slightly improves the mechanical properties of mortars additivated with Pennisetum setaceum fibres.

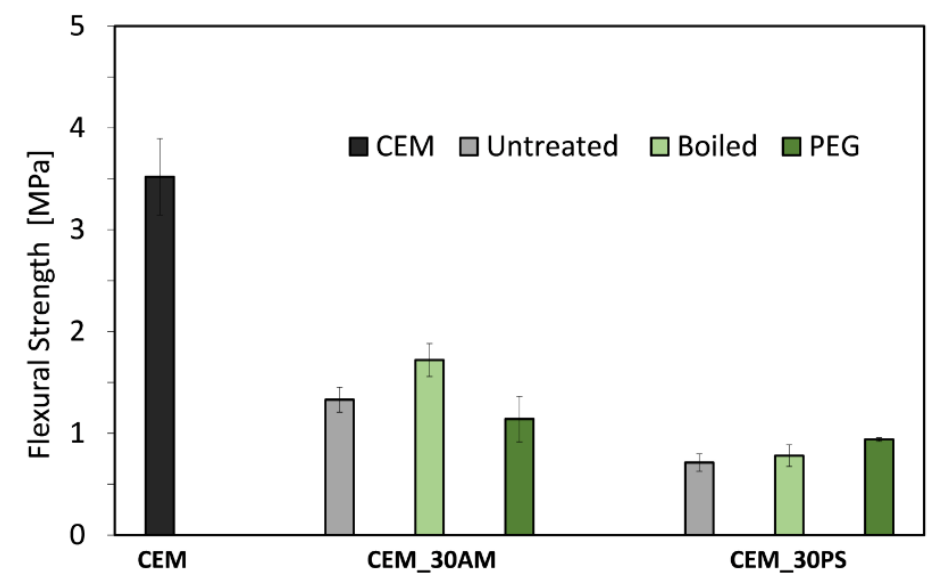

Figure 10. Three-point bending test results.

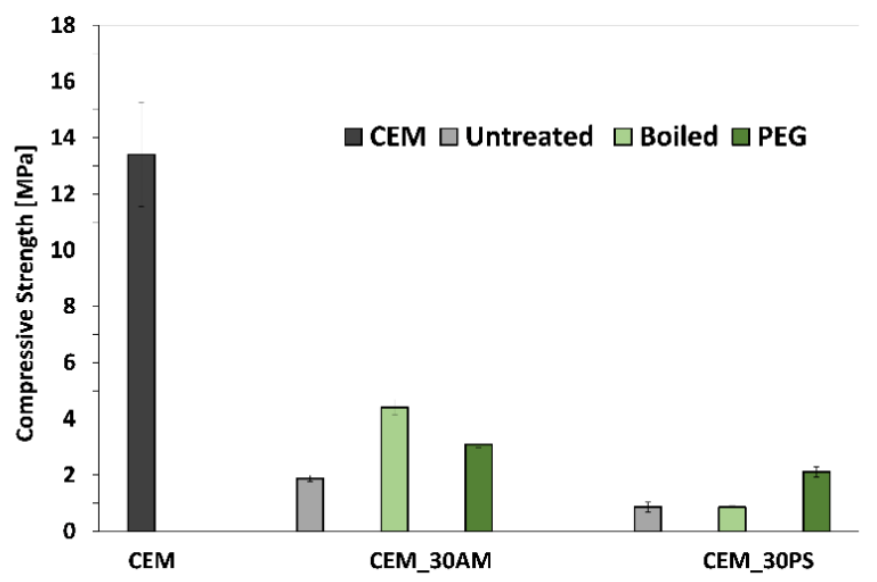

Figure 11. Compression test results.

Overall, the results of the heat flow meter tests reported in Figure 12, evidenced the significant contribution of both the aggregates in reducing the thermal conductivity of the mortars in comparison with the reference one. This result is in accordance with what was obtained by Saghrouni et al. who evidenced a decrease in the thermal conductivity in function of the fiber percentage for Juncus Maritimus fibrous mortar composites [4]. Other works ascribe the reduction of the thermal conductivity to the decrease in the density and correspondent increase in the water absorption in function of the fiber percentage $[6,7,22,23]$. Thermal conductivity of CEM_30PS mortar is slightly lower than CEM_30AM probably due to the lower thermal conductivity of the crimson fountaingrass fibers. The thermal treatment of the diss fibers leads to significantly worse thermal insulating properties, compared to the untreated ones. It can be justified by the slightly higher apparent density (Figure 13) and the lower porosity (Figure 14) of the mortars additivated with boiled fibers compared to those additivated with untreated ones due to the better compatibility between the mortar and the thermal treated aggregate. The thermal treatment does not significantly affect the thermal properties of Pennisetum setaceum mortars. It has to be considered that the higher values of thermal conductivity obtained by both the types of mortars additivated 
with PEG treated aggregates can be attributable to the higher amount of residual water inside the test specimens due to the presence of PEG 4000 which may act as a sealant of the surface of the aggregates. The major amount of entrapped water, filling the porosity of the mortars, can lead to an overestimation of their thermal conductivity.

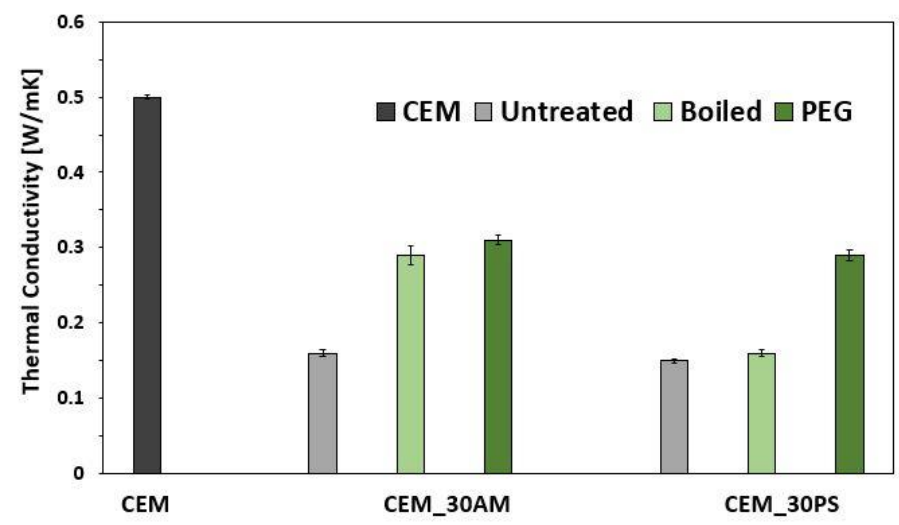

Figure 12. Heat flow meter test results.

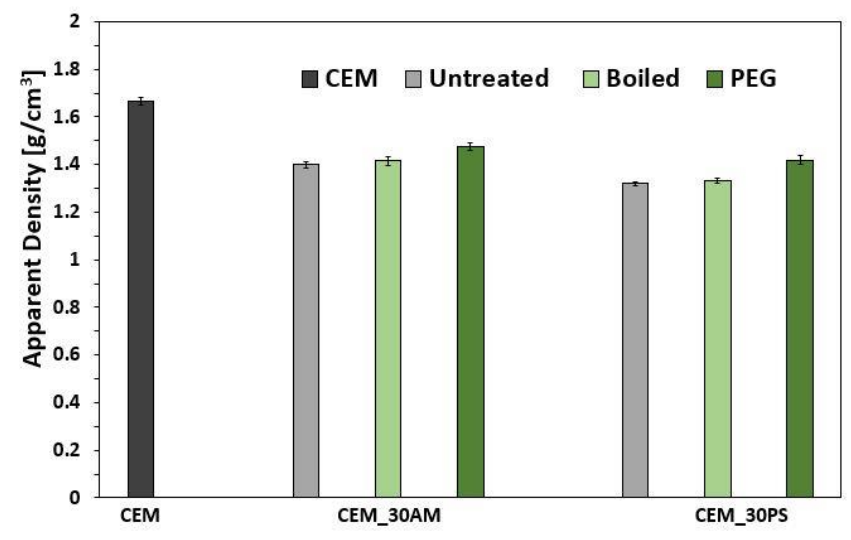

Figure 13. Apparent density of the proposed mortars.

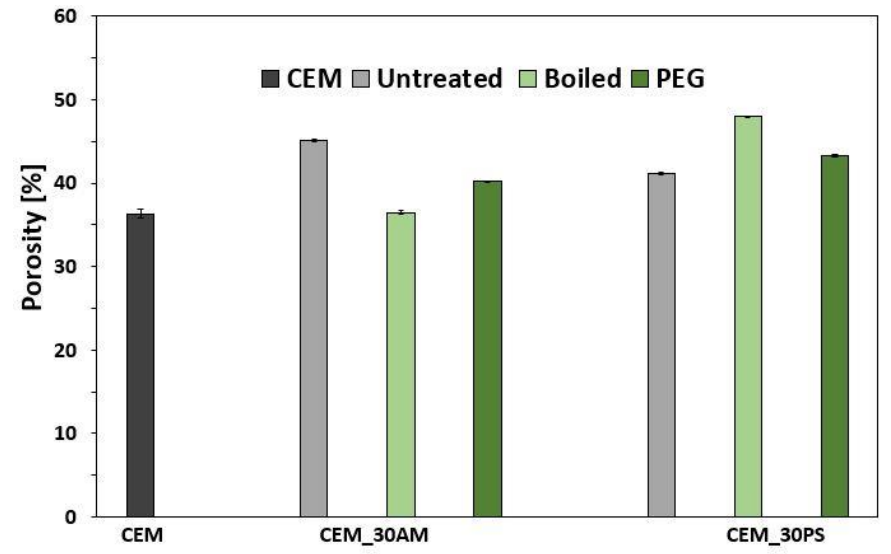

Figure 14. Helium picnometry results.

In Figure 13 are reported the results of the apparent density of the proposed mortars. As expected, the apparent densities of the CEM_30PS mortars are slightly lower compared to the correspondent CEM_30AM ones due to the lower apparent density of the Pennisetum setaceum aggregates with respect to the Ampolodesmos mauritanicus ones (Table 1). The thermal treatment of the aggregates does not significantly affect the apparent 
density of the mortars while the chemical treatment leads to a moderate increase in this physical property due to the PEG impregnation of the aggregates which causes the reduction of their internal voids. In Figure 14, the values of porosity of the mortars are reported. It is evident that the boiling treatment leads to a reduction of the porosity for the CEM_30BAM mortars compared to the CEM_30AM ones that further demonstrates the effectiveness of the thermal treatment to improve the compatibility between Ampelodesmos mauritanicus and the cement matrix as also confirmed by the results of mechanical and thermal tests. On the other hand, the opposite result was recorded for the CEM_30BPS mortars that evidenced a significant increase in the porosity that justifies the decay of the mechanical properties due to incompatibility between the thermal treated aggregate and the matrix. Finally, the boiling and subsequent PEG treatment led to a slight improvement of the physical and mechanical properties of the mortars additivated with Pennisetum setaceum aggregate, while it is pejorative for those additivated with Ampelodesmos mauritanicus aggregate due to the worse fiber-matrix interface.

\section{Conclusions}

In this work two species of plants, i.e., diss (Ampelodesmos mauritanicus) and crimson fountaingrass (Pennisetum setaceum) as aggregates of green concretes have been compared for application as insulating plasters. In particular, the possibility of using the more invasive crimson fountaingrass in place of diss, has been investigated. The characterization of the fibers demonstrated that both from chemical and morphological point of view, diss fibers are preferable to crimson fountaingrass as also confirmed by the mechanical results. Although boiling treatment of diss fibers significantly improves flexural and compression strength of the mortar, the effect on the insulating properties is extremely detrimental and may limit their use as aggregates for insulating plasters. In future works further physical and chemical treatments on Pennisetum setaceum will be investigated in order to improve the compatibility with the cement matrix and encourage their use in place of diss for green concretes.

Author Contributions: Conceptualization, B.M., T.L.M. and A.V.; methodology, B.M. and D.B.; validation, B.M., D.B. and A.V.; formal analysis, B.M. and D.B.; investigation, B.M., D.B. and C.S.; resources, B.M. and A.V.; data curation, B.M., D.B and C.S.; writing-original draft preparation, D.B.; writing-review and editing, D.B. and B.M; supervision, A.V.; project administration, A.V. All authors have read and agreed to the published version of the manuscript.

Funding: This research received no external funding.

Data Availability Statement: All data is contained within the article.

Conflicts of Interest: The authors declare no conflict of interest.

\section{References}

1. Mohanty, A.K.; Misra, M.; Drzal, L.T. Sustainable bio-composites from renewable resources: Opportunities and challenges in the green material world. J. Polym. Environ. 2002, 10, 19-26. [CrossRef]

2. Monteiro, S.N.; Lopes, F.P.D.; Ferreira, A.S.; Nascimento, D.C.O. Natural fibre polymer matrix composites: Cheaper, tougher and environmentally friendly. JOM Member J. TMS 2009, 61, 17-22.

3. Maier, M.; Javadian, A.; Saeidi, N.; Unluer, C.; Taylor, H.K.; Ostertag, C.P. Mechanical Properties and Flexural Behavior of Sustainable Bamboo Fiber-Reinforced Mortar. Appl. Sci. 2020, 10, 6587. [CrossRef]

4. Saghrouni, Z.; Baillis, D.; Naouar, N.; Blal, N.; Jemni, A. Thermal Properties of New Insulating Juncus Maritimus Fibrous Mortar Composites/Experimental Results and Analytical Laws. Appl. Sci. 2019, 9, 981. [CrossRef]

5. Kim, M.J.; Kim, H.G.; Lee, Y.J.; Kim, D.H.; Jo, M.S.; Kim, K.H. Evaluation of Bond Properties of a Fabric-Reinforced Cementitious Matrix for Strengthening of Concrete Structures. Appl. Sci. 2020, 10, 3767. [CrossRef]

6. Badagliacco, D.; Megna, B.; Valenza, A. Induced Modification of Flexural Toughness of Natural Hydraulic Lime Based Mortars by Addition of Giant Reed Fibers. Case Stud. Constr. Mater. 2020, 13, e00425. [CrossRef]

7. Savastano, H., Jr.; Warden, P.G.; Coutts, R.S.P. Brazilian waste fibres as reinforcement for cement-based composites. Cem. Concr. Compos. 2000, 22, 379-384. [CrossRef]

8. Sellami, A.; Merzoud, M.; Amziane, S. Improvement of mechanical properties of green concrete by treatment of the vegetals fibres. Constr. Build. Mater. 2013, 47, 1117-1124. [CrossRef] 
9. Badalamenti, E.; Militello, M.; La Mantia, T.; Gugliuzza, G. Seedling growth of a native (Ampelodesmos mauritanicus) and an exotic (Pennisetum setaceum) grass. Acta Oecol. 2016, 77, 37-42. [CrossRef]

10. Williamson, M. Biological Invasions; Chapman \& Hall: London, UK, 1996.

11. Brullo, C.; Brullo, S.; Del Galdo, G.G.; Guarino, R.; Minissale, P.; Scuderi, L.; Siracusa, G.; Sciandrello, S.; Spampinato, G. The Lygeo-Stipetea class in Sicily. Ann. Bot. 2010, 4, 57-84.

12. Corona, P.; Badalamenti, E.; Pasta, S.; La Mantia, T. Carbon storage of Mediterranean grasslands. An. Jard. Bot. Madr. 2016, 73, 1-8. [CrossRef]

13. Merzoud, M.; Habita, M.F. Elaboration of a Lignocellulosic Composite Formulated with a Local Resource: Diss as Infill in Structures Submitted to Seismic Actions. Res. J. Appl. Sci. 2007, 2, 410-415.

14. Touati, Z.; Boulahia, H.; Belhaneche-Bensemra, N.; Massardier, V. Modification of Diss Fibres for Biocomposites Based on Recycled Low- Density Polyethylene and Polypropylene Blends. Waste Biomass Valori. 2018, 10, 2365-2378. [CrossRef]

15. Achour, A.; Ghomari, F.; Belayachi, N. Properties of cementitious mortars reinforced with natural fibres. J. Adhes. Sci. Technol. 2017, 31, 1938-1962. [CrossRef]

16. Merzoud, M.; Fertikh, S.; Habita, M.F. Influence of absorption by immersion and capillary on the physico-mechanical properties of composites made from local natural fibres. Rabat INVACO2 2011, 77, 37-42.

17. Yahiaoui, L. Characterization of to Rupture of Composite Based with Vegetable Fibres (Diss). Master's Thesis, Ferhat Abbas University, Setif, Algeria, 2011.

18. Pasta, S.; Badalamenti, E.; La Mantia, T. Tempi e modi di un'invasione incontrastata: Pennisetum setaceum (Forssk.) Chiov. (Poaceae) in Sicilia. Nat. Sicil 2010, 34, 163-201.

19. Giosuè, C. Innovative Multifunctional Materials with Low Environmental Impact for Energy Saving, Comfort and Health of Indoor Environment. Ph.D. Thesis, Università Politecnica delle Marche, Ancona, Italy, 2017.

20. Bilba, K.; Arsene, M.A.; Ouensanga, A. Sugar cane bagasse fibre reinforced cement composites. Part I. Influence of the botanical components of bagasse on the setting of bagasse/cement composite. Cem. Concr. Compos. 2013, 25, 91-96. [CrossRef]

21. Peschard, A.; Govin, A.; Pourchez, J.A.E.; Fredon, E.; Bertrand, L.; Maximilien, S.; Guilhot, B. Effect of polysaccharides on the hydration of cement suspension. J. Eur. Ceram. Soc. 2006, 26, 1439-1445. [CrossRef]

22. Eusebio, D.A.; Cabangon, R.J.; Warden, P.G.; Coutts, R.S.P. The manufacture of wood fibre reinforced cement composites from Eucalyptus pellita and Acacia mangium chemithermomechanical pulp. In Proceedings of the Second Panel Product Symposium, Llandudno, Wales, UK, 21-22 October 1998; pp. 428-436.

23. Soroushian, P.; Marinkute, S.; Won, J.-P. Statistical evaluation of mechanical and physical properties of cellulose fiber reinforced cement composites. ACI Mater. J. 1995, 92, 172-180. 